\title{
Pengaruh Informasi Managemen Dalam Pengelolaan Dana dan Pemberdayaan Masyarakat Gampong
}

\author{
Marah sutan Rangkuti ${ }^{1 *}$, Marzuki $^{1}$ dan $^{\text {Agusmadi }^{1}}$
}

${ }^{1}$ Fakultas Ekonomi Program Studi Ekonomi Manajemen Universitas Abulyatama, Aceh Besar, 23372, Indonesia.

*Email korespondensi: rangkuti1313@gmail.com

Diterima 31 Desember 2018; Disetujui 17 April 2019; Dipublikasi 30 April 2019

\begin{abstract}
The purpose of this study was to describe the management of Gampong Fund Management Information in empowering the gampong community and to find out some of the possible and hindering influences in managing gampong funds. This study used descriptive qualitative method. This activity was carried out in Ulee Pata Village, Jaya Baru Subdistrict, Banda Aceh Regency, by conducting interviews and observations to obtain the necessary data and collect information relating to the management of gampong fund management information that had been interpreted. The results of this study indicate that the gampong fund management process carried out by the gampong government has not been completely transparent, the gampong community has not actively participated, and village government officials are more dominant in planning activities and the implementation of gampong funds from 3 hamlets has not been active and still struggling on infrastructure development. The management of village funds has not been aligned towards community empowerment in the context of giving birth to economic income sources, but is still very large for infrastructure development. Empowerment activities are prioritized for physical empowerment such as road construction, rental housing, opening new roads and multi-purpose buildings, while empowering non-physical is associated with minimal training for residents in need. The results of the study indicate that the supporting factors of village fund management in empowering the village community in Ulee Pata Village are support for policy / regulation, socialization, facilities, and infrastructure. The inhibiting factor is a lack of human resources and a lack of community participation in the village.
\end{abstract}

Keywords: community empowerment, management, village funds

Abstrak :Tujuan dari penelitian ini adalah untuk mendeskripsikan pengelolaan manajemen informasi manajemendanagampong dalam memberdayakan masyarakat gampong dan untuk mencari tahu beberapa pengaruh yang memungkinkan dan menghambatdalam mengeloladanagampong. Penelitian ini menggunakan metode deskriptif kualitatif. Kegiatan ini dilakukan di Gampong uleePata, Kecamatan Jaya Baru, Kabupaten Kota Banda Aceh dengan melakukan wawancara dan observasi untuk mendapatkan data-data yang di perlukan dan mehimpun informasi yang berhubungan dengan pengelolaan informasi pengelolaan dana gampong yang telah diinterpretasikan. Hasil dari penelitian in i menunjukkan bahwa proses pengelolaan dana 
gampong yang dilakukan oleh pemerintah gampong belum transparan secara menyeluruh, masyarakat gampong tidak berpartisipasi secara aktif, dan pejabat pemerintah gampong lebih dominan dalam merencanakan kegiatan dan pelaksanaan danagampong dari 3 dusun belum berperan secara aktif dan masih berkutat pada pembangunan infrastruktur. Pengelolaan dana gampong belum ada keberpihakan kearah pemberdayaan masyarakat dalam kontek melahirkan sumber pendapatan ekonomi, akan tetapi masih sangat besar porsi nya untuk pembangunan infrastruktur, Kegiatan pemberdayaan diprioritaskan untuk pemberdayaan fisik seperti pembangunan jalan, rumah sewa, buka jalan baru dan gedung serba guna, sementarapemberdayaan non-fisik terkait dengan pelatihan ketrampilan bagi warga yang membutuhkan sangat minim. Hasil penelitian menunjukkan bahwa faktor-faktor pendukung pengelolaan dana gampong dalam memberdayakan masyarakat gampong di Gampong Ulee Pata adalah dukungan untuk kebijakan/peraturan, sosialisasi, fasilitas, dan infrastruktur. Faktor penghambat adalah kurangnya sumberdaya manusia dan kurangnya partisipasi masyarakat gampong.

KataKunci: pemberdayaan masyarakat, manajemen, dana gampong.

UU Nomor 6 Tahun 2014 tentang Desa disambut dengan suka cita oleh Pemerintah Gampong beserta dengan masyarakatnya yang membuat gampong dalam membangun kearah yang lebih maju dan mandiri sehingga akan tercapai masyarakat yang sejahtera. Asas rekognisi dan subsidiaritas yang ikut melandasi pengembangan substansi Undang-Undang (UU) Desa merupakan kata kunci penting yang mengandung konsekuensi diberikannya kewenangan yang lebih luas serta alokasi anggaran lebih besar Pemernah Gampong guna mendukung kemandirian gampong karah yang lebih bermartabat dan sejahtera.

Kemiskinan merupakan masalah yang sangat kompleks akan teratasi dengan adanya UU No. 6 Tahun 2014, gampong dengan anggaran yang begitu besar harus mampu menggali potensi sumber daya alam, kondisi ini sejatinya bisa mensejahterakan masyarakat gampong, baik masyarakat yang mempunyai skill maupun yang tidak punya skill. Data masyarakat miskin yang dikeluarkan oleh Badan Pusat Statistik (BPS) seringkali menjadi bahan perdebatan terutama dalam kalangan politisi dan akademisi. Sebenarnya melihat data kemiskinan di Indonesia khususnya di Aceh relatif mudah apabila dilihat dari indikator utama kemiskinan yang telah di keluarkan oleh pemerintah kota, terkait dengan pemenuhan kebutuhan primer, maka realitas masyarakat Aceh masih banyak yang sulit memenuhi kebutuhan dasar tersebut.

Menanggapi permasalahan tersebut, maka strategi pembangunan Gampong yang berbasis transparansi informasi yang dilakukan pemerintah gampong saat ini, harus banyak melibatkan Kepala dusun, tokoh dan pemuda, dan masyarakat. Pembangunan gampong merupakan bagian yang sangat penting serta bernilai strategis bagi kemajuan dan kesejahteraan masyarakat gampong, dalam rangka mewujudkan pembangunan nasional dan pembangunan daerah berdasarkan visi dan misi pemerintah pusat dan pemerintah daerah karena didalamnya terkandung unsur pemerataan pembangunan dan serta menyentuh secara langsung kepentingan masyarakat yang bermukim digampong dan dalam rangka upaya 
mengetaskan kemiskinan masyarakat gampong.

Dalam mewujudkan pembangunan pemberdayaan gampong pemerintah gampong merupakan subsistem dari sistem penyelenggaraan pemerintah Indonesia,sehingga gampong memiliki kewenangan, tugas dan kewajiban untuk mengatur dan mengurus kepentingan masyarakarat gampong yang bersangkutan.

Dalam konsep Nawacita yang menjadi program prioritas pembangunan jangka pendek dan jangka panjangsekarang ini terdapat salah satu prioritas pembangunan yaitu membangun masyarakat Indonesia dari pinggiran dengan memperkuat daerah-daerah dan gampong dalam bingkai Negara Kesatuan Republik Indonesia. Oleh karena itu terbitnya undang-undang nomor 6 tahun 2014 tentang Gampong yang bertujuan menciptakan gampong yang mandiri dan sejahtera bagi rakyat indonesia. Memberdayakan masyarakat gampong secara optimal menurut potensi yang ada digampong dan serta ketentuan yang mengatur tentang sumber dana gampong untuk menyelenggarakan pembangunan yaitu Peraturan Pemerintah Nomor 60 tahun 2014 tentang dana gampong serta Peraturan Pemerintahan Nomor 43 Tahun 2014 tentang peraturan pelaksanaan undang-undang nomor 6 tahun2014 tentang gampong.

Tujuan pemberian dana gampong yang bersumber dari anggaran pendapatan dan belanja negara (APBN) yaitu diprioritaskan untuk pembangunan dan pemberdayaan masyarakat. Oleh karena itu dapat diartikan bahwa dana gampong yang berasal dari pusat tidak hanya diprioritaskan untuk pembangunan infrastruktur gampong dan pemberdayaan masyakarat gampong.

Hal ini dijelaskan dalam Peraturan Pemerintah Nomor 60 tahun 2014 tentang Dana Gampong yang bersumber dari Anggaran Pendapatan Dan Belanja Negara, pada pasal 19 ayat (2) dijelaskan bahwa dana gampong sebagaimana dimaksud ayat(1) diprioritaskan untuk membiayai pembangunan dan pemberdayaan masyarakat Gampong.

Menurut (Yuliana, Rahmawati, Adamy, Edwar, \& Azlim, 2018) untuk menilai efektivitas alokasi dana desa dapat dilihat dari rasio efektivitas yang merupakan fungsi dari realisasi Anggaran Dana Desa (ADD) dan Target ADD.

Gampong Ulee Pata terdiri dari 3 (tiga) yaitu Dusun Silva lambaroeh, Dusun Abubakar dan Dusun Muhammad dengan jumlah penduduk lebih kuran 675 orang merupakan salah satu gampong yang menerima dana gampong yang berasal dari Anggara Pendapatan dan BelanjanNegara (APBN). Pengelolaan dana gampong dimulai dari perencanaan program, penetapan serta pelaksanaan dan dipertanggungjawabkan. Pengelolaan dana gampong disesuaikan dengan kebutuhan masyarakat dan prioritas program yang ditetapkan oleh pemerintahan gampong. Berdasarkan penelitian awal yang peneliti lakukan, diperoleh informasi dari masyarakat yang mengatakan bahwa pengelolaan dana gampong digampong Ulee Pata masih terdapat ketidak transparansi, mulai dari perencanaan, 
pelaksanaan dan pada laporan pertanggung jawaban kegiatan gampong.

Pada tahap perencanaan penggunaan dana gampong lebih cenderung pada program yang akan dilaksanakan berdasarkan rencana kepala gampong sehingga pada saat musrenbang gampong masyarakat yang hadir hanya sebatas untuk mendengar dan mengetahui. Program kegiatan yang dilaksanakan oleh pemerintah gampong tidak sepenuhnya diketahui dan dipahami oleh masyarakat sebab informasi program yang terpangpang di papan informasi sangat umum sehingga tidak mudah bagi masyarakat untuk mengetahui kegiatan apasaja yang akan di lakukan di tahun berjalan.

Bentuk kegiatan yang dilakukan untuk meningkatkan keberdayaan masyarakat lebih kepada pembangunan fisik dan pengiriman beberapa orang kampung ke tempat Pelatihan dengan satu jenis kegiatan dan yang telah dilatih di tahun berikutnya tidak program pemberdayaan terhadap masyarakat yang dilatih sehingga pemborosan anggaran. Hal ini berimplikasi pada partisipasi masyarakat yang cenderung patis pada kegiatan yang dilakukan dari dana gampong dan ini juga berdampak pada pertanggung jawaban yang tidak transparan.

\section{METODEPENELITIAN}

Jenis penelitian yang digunakan dalam penelitian ini adalah motode penelitian deskriptif dengan pendekatan kualitatif. Penelitian ini dilaksanakan disatu gampong diKota Banda Aceh yaitu GampongUlee Pata Kecamatan Jaya Baru.

Alasan pemilihan lokasi penelitian yaitu yang pertama karena gampongUlee PataKecamatanJaya baru merupakan gampong di ujung kota Banda Aceh dan merupakan salah satu gampong yang berdekatan dengan laut dan rawa.

Alasan yang kedua di Gampong Ulee Pata Kecamatan Jaya Baru merupakan gampong yang masih banyak masyarakat miskin dan kualitas fasilitas umum yang kurang memadai. Alasan yang ketiga yaitu belum adanya yang malakukan penelitian ditempat ini atau di Ulee Pata tentang pengelolaan dana gampong dalam Pemberdayaan masyarakat gampong. Yang menjadi kriteria informan dalam penelitian ini adalah:

1. Orang yang memahami secara mendalam kondisi Gampong Tetehosi Sorowi, dalam hal ini peneliti mewawancarai Kepala Gampong, Badan Permusyarawatan Gampong, Sekretaris Gampong, Bendahara Gampong.

2. Masyarakat asli Gampong Ulee Pata yang sudah berumur lebih dari 30 tahun, dalam penelitian ini berjumlah 60 orang masyarakat yang peneliti pilih menjadi informan.

3. Data primer dikumpulkan melalui melalui observasi atau pengamatan secara langsung serta wawancara dengan para informan yang telah ditentukan. Data sekunder diperoleh melalui kajian pustaka,buku,serta jurnal. 


\section{HASIL DAN PEMBAHASAN}

Gampong Ulee Pata merupakan salah satu gampong yang menerima dana gampong yang berasal dari Anggaran Pendapatan dan Belanja Negara (APBN).

Pengelolaan dana gampong dimulai dari Rapat Masyarakat, perencanaan program serta pelaksanaan dan setelah dilaksanakan dipertanggung jawabkan. Pengelolaan dana gampong disesuaikan dengan kebutuhan masyarakat serta prioritas program yang ditetapkan oleh pemerintahan gampong ini yang menjadi ketidak transparansi dan pemberdayaan masyarakat yang kurang.

Berdasarkan penelitian awal yang peneliti lakukan, diperoleh informasi dari masyarakat yang mengatakan bahwa pengelolaan dana gampong digampong Ulee Pata masih terdapat banyak ketidak transparan, mulai dari perencanaan, pelaksanaan dan sampai dengan pelaporan pertanggungjawaban kegiatan gampong.

\section{Pengelolaan Dana Gampong Dalam Pemberdayaan Masyarakat Gampong}

\section{Perencanaan Dana Gampong}

Perencanaan adalah suatu kegiatan untuk mempersiapkan dan menentukan sesuatu tujuan yang ingin dicapai dimasa yang akan datang serta menetapkan program dan tahapan yang akan dilalui untuk mencapai tujuan tersebut. Kegiatan perencanaan awal merupakan titik tolak yang sangat penting untuk mencapai tujuan dari sebuah program kegiatan yang direncanakan. Oleh karena itu setiap program kegiatan yang akan dilaksanakan dengan langkah awal adalah melakukan observasi kemasyarakat, mewawancarakan masyarakat, dan menhinpun semua keinginan masyarakat, baru setelah itu direncanakan secara matang diklasifikasikan antara prioritas dan tidak prioritas, setelah itu di musyawarah kembali terhadap program yang sudah di perioritas dan tidak prioritas agar masyarakat bisa tahu dan mengerti terhadap program yang telah didusun tersebut sebelun di sahkan oleh pemerintah ganpong, dalam hal untuk menentukan tujuan kegiatan bersama dalam sebuah organisasi yang telah ditetapkan untuk tercapai secara maksimal, tepat kebutuhan dan tepat keinginan masyarakat dalam kontek membangun gampong yang mandiri dan sejahtera.

Dalam perencanaan keuangan gampong khususnya pengelolaan dana dibutuhkan sebuah perencanaan program kegiatan kegiatan yang sesuai dengan potensi, ekonomi, sosial masyarakat dan kearifan lokal yang ada di gampong tersebut.

Dana Gampong merupakan salah satu pendapatan gampong yang bersumber dari Anggaran Belanja dan Pendapatan Negara (APBN) yang penggunaannya terintegrasi dengan Anggaran Pendapatan dan Belanja Gampong (APB Gampong), oleh karena itu perencanaan program kegiatan disusun secara sistematis dan berkelanjutan dengan terlebih dahulu dilaksanakanya Musyawarah Perencanaan dengan masyarakat, mulai dari tingkat dusun sampai pada tingkat gampong dengan melibatkan unsur Tuha Peut, PKK, 
Pemuda, Perangkat Gampong, Pendamping Gampong dan tokoh masyarakat serta masyarakat secara keseluruhan.

Tujuan Dana Gampong yaitu untuk pembangunan dan pemberdayaan masyarakat. Oleh karena itu tujuan dari pemberian dana gampong yang bersumber dari Anggaran Belanja dan Pendapatan Negara memiliki dua prioritas utama yaitu pembangunan dan pemberdayaan, maka tidak berarti hanya membangunan fisik saja yang diutamakan namun juga pemberdayaan masyarakat gampong sehingga menumbuh kembangkan ekonomi kemandirian gampong dalam memenuhi kebutuhan hidup dan terlepas dari belenggu kemiskinan.

Dari hasil penelitian langsung dilapangan dapat dilihat bahwa perencanaan program meningkatkan pemberdayaan masyarakat dari dana gampong, masyarakat belum terlibat aktif masyarakat yang diundang kemusyawarah perencanaan dan pembangunan gampong namun usul kegiatan dan tempat pelaksanaan kegiatan lebih banyak ditentukan oleh perangkat gampong. Hal ini terbukti dengan hasil temuan dilapangan masyarakat menganggap kegiatan musyawarah perencanaan dan pembangunan gampong sebagai kegiatan formalitas serta hasil pertanggung jawan pemerintah gampong di akhir juga tidak dilakukan. Anggapan ini terjadi karena penentuan program dan kegiatan yang dilakukan lebih didominasi oleh perangkat gampong sedangkan masyarakat hanya sebagai menonton yang pasif dalam penentuan kegiatan. Hal ini bertolak belakang dengan defenisi pemberdayaan yang dipaparkan oleh Djohani (dalam Haryono 2012 : 49) yang mengatakan bahwa pola dasar gerakan pemberdayaan mengamanatkan perlunya power (kekuatan) dan keberpihakan pemimpin gampong kepada kelompok yang tidak berdaya atau ekonomi lemah. Oleh karena itu pemberdayaan adalah suatu proses untuk memberikan daya/kekuasaan kepada pihak yang lemah (powerless), dan mengurangi kekuasaan (disempowered) kepada pihak yang terlalu berkuasa (powerful) sehingga terjadi keseimbangan antara yang lemah ekonomi dan yang kuat ekonomi. Dari hasil penelitian langsung tersebut dapat digambarkan melalui skema sebagai berikut:

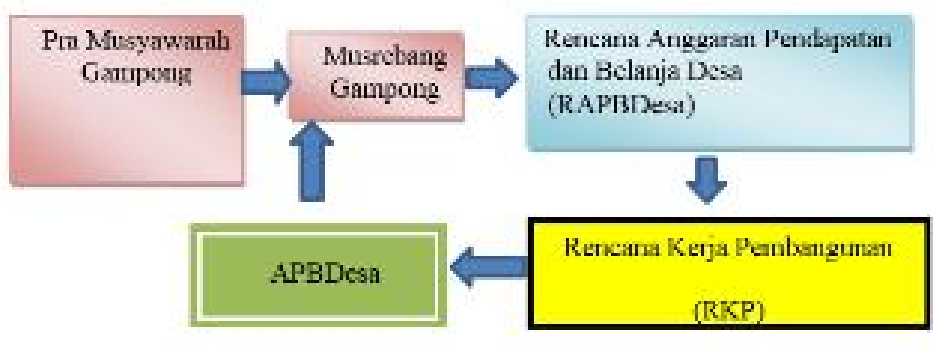

Gambar 1. Skema Perencanaan Program

Dari skema diatas pada perencanaan penggunaan dana gampong yang terintegrasi dalam Anggaran Pendapatan dan Belanja Gampong (APBGampong) yaitu :

\section{Pra Musyawarah Perencanaan dan Pembangunan Gampong}

Pra Musrenbang gampong merupakan wadah menghimpun semua aspirasi dan keinginan masyarakat untuk merencanakan kegiatan berdasarkan kebutuhan yang diprioritaskan yang sesuai dengan keinginan dan potensi SDM, SDA di 
gampong tersebut. pra Musrebang gampong dilaksanakan pada bulan juli tahun anggaran berjalan dengan turut mengundang berbagai unsur masyarakat, tokoh agama, tokoh adat dan dihadiri warga atau masyarakat secara keseluruhan atau bisa di lakukan di tiap-tiap dusun musyawarah tersebut apabila di tiap dusun mempunyai tempat musyawarah.

\section{Musyawarah Perencanaan dan Pembangunan Gampong}

Musrenbang gampong merupakan wadah untuk merencanakan kegiatan berdasarkan kebutuhan yang prioritaskan yang sudah di sepakati pada pra musrenbang gampong yang diselenggarakan oleh pemerintah gampong. Musrebang gampong dilaksanakan pada bulan september tahun anggaran berjalan dengan turut mengundang berbagai unsur masyarakat,tokoh agama,tokoh adat, pendamping gampong dan dihadiri oleh camat sebagai Pembina gampong.

\section{Rencana Kerja Pembangunan (RKP)}

RKP gampong memuat rencana penyelenggaraan pemerintah gampong, pelaksanaan pembangunan, pemberdayaan masyarakat gampong. RKP gampong berisi tentang evaluasi-evaluasi RKP tahun sebelumnya, prioritas program, kegiatan dan anggaran gampong yang dikelola oleh pihak ketiga serta kewenangan penugasan dari tingkat pemerintah yang lebih tinggi. RKP disusun paling lama bulan september atau oktober sebelum tahun anggaran berjalan karena RKP akan menjadi dasar untuk penyusunan anggaran pendapatan dan belanja gampong.

\section{Rencana Anggaran Pendapatan dan Belanja Gampong}

Rencana Anggaran Pendapatan dan Belanja Gampong disusun setelah dibuat Rencana Kerja Pembangunan (RKP). RAPB gampong diusulkan kepada Bupati melalui camat, apabila disetujui oleh bupati maka pemerintah gampong akan mengesahkan RAPB Gampong tersebut menjadi APBGampong.

\section{Anggaran Pendapatan dan Belanja Gampong Anggaran Pendapatan dan Belanja gampong}

Merupakan kegiatan dan sumber pendapatan dan biaya kegiatan tersebut. Dalam APB Gampong yang merupakan salah satu sumber pendapatannya yaitu dana gampong.

\section{Pelaksanaan Dana Gampong}

Pelaksanaan tindakan penting untuk mewujudkan tujuan akhir yang telah ditetapkan dari setiap kegiatan yang telah direncanakan secara matang dan terperinci melalui perencanaan atau Musrenbang.

Pelaksanaan kegiatan akan dilakukan setelah program tersebut dikatakan telah sah dan siap diimplementasikan. Setiap tahunnya bupati nias utara menetapkan surat tentang pelaksanaan pengelolaan dana gampong yang membantu perangkat gampong. Dikeluarkan Peraturan Bupati Nias Utara nomor 
412.6/k/tahun 2016 tentang petunjuk teknis pelaksanaan pengelolaan keuangan gampong diKabupaten Nias Utara menjadi pedoman pelaksanaan pengelolaan keuangan gampong.

Kepercayaan masyarakat yang kurang kepada pemerintah gampong dalam pelaksanaan dana gampong menjadi unsur negatif yang membuat pelaksanaan kegiatan tidak maksimal karena tidak mendapat dukungan dari masyarakat. Dari hasil penelitian pelaksanaan dana gampong tersebut mendapat ketidak percayaan masyarakat kepada pihak pelaksana kegiatan dalam hal ini perangkat gampong. Hal ini disebabkan karena ketidak terbukaan atau tidak ada transparansi secara nyata penggunaan dana gampong.

Masyarakat berdalih bahwa yang mengetahui penggunaan dana gampong telah memenuhi syarat untuk sebuah kegiatan hanya perangkat gampong, masyarakat biasa tidak mengetahui standar perlaksanaanya sebuah program yang telah dilaksanakan tersebut. Selain itu pelaksanaan dana gampong dalam pemberdayaan masyarakat gampong mendapat kritikan dari masyarakat karena pelaksanaan kegiatan tersebut dinilai hanya formalitas semata, hal ini disebabkan karena pengelolaan yang tidak transparan oleh perangkat gampong. Pemberdayaan masyarakat dirancang berkelanjutan dan memamfaat kan potensi SDM yang ada di gampong tersebut, seperti yang dijelaskan oleh Zubaedi (2012) yang mengatakan bahwa pemberdayaan masyarakat sejalan dengan prinsip pembangunan yang bekelanjutan dan berkesinambungan jika program dirancang dan dilaksanakan dengan memperhatikan keberlanjutan dari segi ekonomi dan sosial serta kearifan lokal.

\section{Pertanggungjawaban}

Pertanggung jawaban dana gampong tidak terintegrasi dengan petanggung jawaban APB Gampong, sehingga pertangung jawaban dana gampong harus dibuat terpisah dengan laporan LPPG. Kepala gampong menyampaikan laporan realisasi dana gampong setelah penyampaian laporan di ketahui oleh Tuha Peut dan di kirim ke camat untuk dilaoporkan hasil LPPG kepada Walikota. Pembuatan laporan yang dilakukan pemerintah gampong yaitu dengan menggunakan bantuan pihak ketiga.

Laporan realisasi penggunaan dana gampong semester pertama disampaikan paling lambat pada akhir bulan juli tahun berjalan dan laporan semester akhir tahun disampaikan paling lambat pada akhir bulan januari tahun berikutnya. Pertanggungjawaban pengelolaan dana gampong telah sesuai dengan peraturan yang berlaku. Namun belum ada pertanggungjawaban langsung kepada masyarakat seperti apa hasil dari dana gampong tersebut. Pengelolaan dana gampong yang dilaksanakan oleh perangkat/kaur, penting untuk melibatkan masyarakat langsung, sebagai warga dari gampong yang menjadi sasaran dari program dana gampong, sudah harusnya semua semua unsur masyarakat dilibatkan/terlibat dalam pengelolaan dana gampong dan mengetahui pengelolaan dana gampong tersebut untuk mendapatkan kepercayaan dari masyarakat, pertanggungjawaban pengelolaan 
dana gampong harus melibatkan masyarakat.

\section{Bentuk-Bentuk Program Dana Gampong}

Untuk Meningkatkan Pemberdayaan Masyarakat

Pemberdayaan dalam bentuk fisik pembangunan sektor infrastukturjalan merupakan salah satu sektor vital untuk memacu pertumbuhan ekonomi dalam meningkatkan pemberdayaan yang pada dasarnya merupakan sektor yang menghubungkan berbagai macam aktivitas ekonomi masyarakat. Pembangunan prasarana jalan memiliki fungsi akses tabilitas untuk membuka daerah yang kurang berkembang dan fungsi mobilitas daerah yang telah berkembang.

Pembangunan jalan dari dana gampong menuju pemukiman warga yang terisolir. Pembangunan infrastruktur jalan menuju pemukiman warga merupakan salah satu kegiatan yang dilaksanakan dari dana gampong dengan tujuan agar terjadi pemerataan pembangunan yang selama ini tidak dirasakan oleh beberapa pihak karena faktor geografis.

Dalam teori Tallcot Parson tentang sistem mengatakan bahwa untuk melakukan suatu tindakan harus ada adaption kebutuhan dengan lingkungan, kebutuhan masyarakat dalam pembangunan infrastruktur jalan merupakan kebutuhan vital yang meningkatkan keberdayaan masyarakat.

Pembangunan jalan berdampak pada aspek social masyarakat tersebut, terbuka jalan warga dirasakan dari aspek social masyarakat yang dulunya warga kampung ini dipandang sebelah mata karena tinggal dekat hutan yang jauh dari jalan umum dan jalan kesana hanya jalan setapak, namun sekarang dengan terbukanya jalan yang layak dan memadai warga marasa derajat sosialnya meningkat.

\section{Infrastruktur Pertanian}

Pembangunan infrastruktur jalan kepertanian masyarakat merupakan salah satu cara mempermudah akses masyarakat untuk melakukan aktivitas bertani. Tempat pertanian yang jauh tepisah dengan tempat pemukiman warga menjadi salah satu faktor untuk melakukan pembangunan jalan untuk menunjang perekonomian masyarakat.

Pembangunan infrastruktur jalan di gampong dibiayai dari dana gampong yang dilakukan secara bertahap. Pembangunan jalan antar dusun tersebut sangat dibutuhkan guna memperlancar aktivitas masyarakat dalam bernelayan dalam beraktivitas. Sebab ekonomi masyarakat masih sulit karena sebab hasil panen tidak menentu. Seperti diketahui bahwa masyarakat GampongUlee Pata mayoritas Nelayan, Pedagang, bengkel, perabot, pns dan buruh dan lain-lain.

Pembangunan infrastruktur jalan menambah semangat karena akses ketempat tambak atau ketampat kerja (bengkel dan perabot banyak berada di dusun), sudah mudah ditempuh dengan kendaraan. Hal ini tidak terlepas dari penyesuaian kebutuhan masyarakat seperti yang dikatakan oleh Tallcot Parson yaitu adaptasi kebutuhan. Kebutuhan masyarakat akan fasilitas jalan yang memudahkan masyarakat dalam melakukan aktivitas pekerjaan, dengan 
tujuan(goal) yaitu untuk meningkatkan kesejahteraan masyarakat melalui fasititas yang memadai. Fasilitas ini memberi dorongan kepada masyarakat untuk lebih semangat bekerja karena akses yang sudah memadai.

\section{Pembangunan Air Bersih}

Air bersih merupakan kebutuhan paling penting dalam kehidupan sehari-hari. Mulai dari sumber air minum, memasak, menyuci dan lainlain sangat membutuhkan air bersih. Kondisi masyarakat gampong yang masih banyak memanfaatkan PDAM. Seperti yang dipaparkan dalam teori sistem yang digagas oleh Tallcot Parson yaitu untuk menentukan suatu tindakan untuk meningkatkan keberdayaan masyarakat harus adanya adaptasi kebutuhan mendasaryaitu kebutuhan sanitasi masyarakat dengan tujuan (goal) memudah masyarakat dalam mendapatkan air bersih untuk keberluan sehari.

\section{Pemberdayaan Masyarakat Non Fisik}

\section{Bimbingan Teknis Untuk Para}

\section{Perangkat Gampong}

Upaya meningkatkan kemampuan perangkat gampong dalam mengelola dana gampong maka dilakukan bimbingan teknis dengan tujuan menyebarluaskan informasi pengalolaan dana gampong. Dalam mengelola dana gampong yang jumlahnya besar dibutuhkan bimbingan kepada perangkat gampong, untuk meminimalisir terjadinya kesalahan dalam mengelola keuangan gampong karena sumber daya manusia yang kurang memadai.Oleh karena itu pelaksanaan bimtek sangat memberi kontribusi yang baik.

Kegiatan bimbingan teknis yang diikuti oleh perangkat Gampong Ulee Pata ada dua yaitu Kegiatan pelatihan pengelolaan dana gampong dan penyerapan dana gampong dan Kegiatan pelatihan pengelolaan dan pertanggungjawaban. Oleh karena gampong dituntut mampu mengelola anggaran yang nilainya cukup besar mencapai Rp1milyar lebih setiap tahunnya. Sehingga kapasitas kepala gampong dan perangkatnya harus lebih ditingkatkan dengan berbagai kegiatan pelatihan ataupun bimbingan teknis (Bimtek). Termasuk kegiatan peningkatan sumberdaya aparatur gampong yang diselenggarakan bagi perangkat gampong belum lama ini dinilai sangat membantu dalam peningkatan kapasitas dan kemampuan perangkat gampong. Peningkatan SDM melalui pelatihan, bimbingan teknis merupakan kebutuhan perangkat gampong seiring perubahan paradigma ,disamping itu banyak perangkat gampong yang baru dilantik dengan latar belakang pendidikan yang bervariatif.

\section{Pemberdayaan}

\section{Kesejahteraan}

\section{Keluarga (PKK)}

Pemberdayaan kesejahteraan keluarga (PKK) merupakan mitra gampong dalam mewujudkan pemberdayaan dan meningkatkan kesejahteraan keluarga. Sebagai mitra gampong dalam mewujudkan tugasnya pemerintah gampong memberi dana yang bersumber dari dana gampong untuk mewujudkan kegiatan PKK.

Kegiatan PKK yang dananya bersumber dari dana gampong bertujuan untuk memberdayakan kelompok wanita gampong untuk meningkatkan keterampilan sebagai 
sumber penghasilan ekonomi. Pemberian dana ini merupakan salah cara memotivasi dan memberi dukungan kepada kaum wanita untuk menggali potensi yang dimiliki untuk meningkatkan kesejahteraan dan membuka akses sumber ekonomi.

Saat ini dari hasil observasi dilapangan bahwa tren pemesan papan bunga untuk berbagai kegiatansemakin meningkat. Hal ini dimafaatkan oleh kaum perempuan Gampong Ulee Pata untuk mengaplikasikan keterampilan mereka untuk berkreasi membuat kue, sulam tangan dan tarian anak anak gampong. Dengan demikian mereka mempunyai sumber penghasilan dari kegiatan tersebut.

Faktor yang Mendukung dan Menghambat Pengelolaan Dana Gampong dalam Memberdayakan Masyarakat Gampong.

Dalam pelaksanaan pengelolaan dana gampong berbagai faktor yang mempengaruhi baik yang sifatnya mendukung maupun faktor yang menjadi penghambat proses pengelolaan dana gampong. Adapun faktor yang mempengaruhi pengelolaan dana gampong dalam pemberdayaan masyarakat Gampong Ulee Pata Kecamatan Jaya Baru sebagai berikut :

\section{Faktor Pendukung}

\section{a. Dukungan Kebijakan}

Kebijakan merupakan konsep yang menjadi pedoman dasar bagi pemerintahan untuk melaksanakan program. Kebijakan berupa peraturan Walikota dan petunjuk teknis Pengaruh Informasi Manajemen....

(Rangkuti, Marzuki, \& Agusmadi, 2019) pelaksanaan pengelolaan keuangan gampong yang menjadi faktor pendukung pengelolaan Dana Gampong.

b. Sosialisasi

Sosialisasi merupakan proses penyampaian pembelajaran kepada kelompok sasaran dari suatu kebijakan.Tujuan sosialisasi yaitu untuk membantu kelompok sasaran kebijakan lebih mengerti kebijakan yang baru yang akan diterapkan kepada masayarakat yang sebelumnya belum diketahui oleh masyarakat.

Sosialisasi membutuhkan proses yang cukup panjang untuk menerapkan peraturan atau program serta kegaitan yang baru. Sosialisasi pengelolaan dana gampong kepada perangkat pemerintah gampong memberi kontribusi yang sangat baik terhadap pengelolaan dana gampong.

\section{c. Sarana dan Prasarana}

Sarana adalah segala sesuatu yang dapat dipakai sebagai alat mencapai tujuan atau sasaran sedangkan prasarana adalah segala sesuatu yang merupakan penunjang utama terselenggaranya suatu proses. Sarana dan prasarana yang ada di Gampong Ulee Pata menjadi penunjang efesiensi dan efektifitas pengelolaan dana gampong.

\section{Faktor Penghambat}

a. Sumber Daya Manusia

Sumber daya manusia yang dimiliki gampong Ulee Pata belum memadai dalam mengelola keuangan gampong disebabkan oleh tingkat pendidikan yang masih rendah sehingga mengakibatkan pengelolaan dana gampong yang 
tidak maksimal karena adanya pengeluaran tambahan untuk dikerjakan oleh pihak ketiga.

\section{b. Partisipasi Masyarakat}

Partisipasi masyarakat adalah keikut sertaan masyarakat secara aktif dalam memberi kontribusi dengan sukarela mulai dari proses perencanaan, sampai evaluasi dari program tersebut. Semakin tinggi tingkat partisipasi masyarakat yang menjadi kelompok sasaran program tersebut maka semakin tinggi tingkat keperhasilan pencapaian tujuan dari program tersebut. Namun sebaliknya jika partisipasi masyarakat tidak maksimal dalam pengelolaan program, pengawasan dan pelibatan pada pelaksanaan tersebut maka tingkat keberhasilan kegiatan tersebut semakin rendah dan digampong ini partisipasinya sangat rendah.

\section{KESIMPULAN}

Perencanaan dana gampong dilakukan dengan cara dilaksanakannya Musrenbang gampong dilaksanakan oleh pemerintah gampong. Pelaksanaan Musrenbang gampong telah dilaksanakan, namun Penentuan kegiatan program masih didominasi oleh perangkat gampong dan keterbukaan informasi masih sangat minim. penyediaan anggaran untuk program pemberdayaan masyarakat gampong sangat minim.

Wujud implementasi yang pembagian dana program lebih banyak kefisik, maka keberlanjutan program pemberdayaan ekonomi berkelanjutan tidak maksimal dan upaya untuk mengentaskan kemiskinan dalam tataran penambahan pendapatan ekonomi masyarakat tidak tercapai dan ini merupakan tanggung jawab pemerintahan gampong, sebagai pelaksanaan dana gampong.

Pertanggung jawaban dana gampong merupakan konsekuensi dari yang direncanakan dan dilaksanakan oleh pemerintah gampong, segala bentuk pengeluaran, pendapatan telah dilaksanakan harus dipertanggung jawabkan oleh perangkat gampong kepada Walikota melalui camat kecamatan.

Faktor pendukung pengelolaan dana gampong yang pertama yaitu dukungan kebijakan harus sesuai dengan RPMG yang telah disusun dari awal.Faktor yang kedua yaitu sosialisasi kepada masyarakat harus tuntas terhadap pengelolaan dana gampong yang telah diikuti oleh perangkat gampong dengan menyediakan informasi dan papan informasi yang mudah untuk di pahami dan di mengerti oleh masyarakat. ketiga adalah sarana dan prasarana pendukung pengelolaan dana gampong harus memadai serta SDM yang digunakan sesuai dengan kebutuhan, dan harus di berikan pendampingan dan pelatihan yang kontinue supaya hasil yang diharapkan dalam penggunaan dana gampong tepat sasaran transparan dan akuntabel.

Faktor penghambat pengelolaan dana gampong yang pertama yaitu sumber daya manusia yang rendah dan keinginan untuk bisa sangat kurang dan tidak fokus pada jabatan yang di emban. Faktor yang selanjutnya yaitu partisipasi masyarakat yang masih dinilai rendah. 


\section{DAFTARPUSTAKA}

Awang, A. (2010). Implementasi

Pemberdayaan Pemerintah Gampong.

Cetakan pertama.Yogyakarta:Pustaka pelajar.

Anwan,O.M. (2014). Pemberdayaan

Masyarakat Diera Global. Bandung:

Alfabeta.

Ambar,T.S.\&Rosidah.(2006). Manajemen

Sumber Daya Manusia. Yogyakarta :

Graha Ilmu.

Adisasmita,R. (2011). Pengelolaan

Pendapatan dan Belanja Daerah.

Yogyakarta: Graha Ilmu.

Bintoro,T.(2000). Teori Strategi

Pembangunan Nasional, Jakarta: P.T.

Gunung Agung.

Bungin, B.(2011). Metodologi Penelitian

Sosial dan Ekonomi: format-format

kuantitatif dan kualitatif untuk studi

sosiologi, kebijakan publik,

manajemen, dan pemasaran. Cetakan:

kedua. Jakarta : Kencana.

Fahrudin, A. (2012). Pengantar

Kesejahteraan Sosial. Bandung: PT.

Refika Aditama.

Faisal,S.(2007). Format-Format Penelitian

Sosial. Jakarta:Raja Grafindo Persada.
Idrus,M.(2009). Metode Penelitian Ilmu Sosial: Pendekatan Kualitatif Dan Kuantitatif. Jakarta: Erl

Yuliana, Y., Rahmawati, C., Adamy, Y., Edwar, E., \& Azlim, A. (2018). The Effectiveness Analysis of Village Funds Management Planning. In Proceedings of AICS-Social Sciences (pp. 37-43).

- How to cite this paper:

Rangkuti, M. sutan, Marzuki, M., \& Agusmadi, A. (2019). Pengaruh Informasi Managemen Dalam Pengelolaan Dana dan Pemberdayaan Masyarakat Gampong. Jurnal Humaniora, 3(1), 48-60. 